\title{
Tectono-thermal evolution in a region with thin-skinned tectonics: the western nappes in the Cantabrian Zone (Variscan belt of NW Spain)
}

\author{
F. Bastida; C. Brime; S. García-López G. \\ N. Sarmiento
}

\begin{abstract}
The palaeotemperature distribution in the transition from diagenesis to metamorphism in the western nappes of the Cantabrian Zone (Somiedo, La Sobia and Aramo Units) are analysed by conodont colour alteration index (CAI) and illite crystallinity (IC). Structural and stratigraphic control in distribution of CAI and IC values is observed. Both CAI and IC value distributions show that anchizonal conditions are reached in the lower part of the Somiedo Unit. A disruption of the thermal trend by basal thrusts is evidenced by CAI and IC values. There is an apparent discrepancy between the IC and CAI values in Carboniferous rocks of the Aramo Unit; the IC has mainly anchizonal values, whereas the CAI has diagenetic values. Discrepant IC values are explained as a feature inherited from the source area. In the Carboniferous rocks of the La Sobia Unit, both IC and CAI indicate diagenetic conditions. The anchimetamorphism predated completion of emplacement of the major nappes; it probably developed previously and/or during the early stages of motion of the units. Temperature probably decreased when the metamorphosed zones of the sheets rose along ramps and were intensely eroded. In the context of the Iberian Variscan belt, influence of tectonic factors on the metamorphism is greater in the internal parts, where the strain and cleavage are always present, than in the external parts (Cantabrian Zone), where brittle deformation and rock translation are dominant, with an increasing role of the burial on the metamorphism.
\end{abstract}

F. Bastida (Y) C. Brime S. García-López

Departamento de Geología, Universidad de Oviedo, E-33005 Oviedo, Spain

Fax: 34985103103

e-mail: bastida@asturias.geol.uniovi.es

G. N. Sarmiento

Departamento de Paleontología, Universidad Complutense, Instituto de Geología Económica (CSIC-UCM),

Facultad de CC Geológicas, E-28040 Madrid, Spain
Key words Conodont colour alteration index. Illite crystallinity. Transition diagenesis-metamorphism. Thrusts. Iberian Variscan belt

\section{Introduction}

The Cantabrian Zone forms the external part of the Variscan belt in the NW Iberian Peninsula and is characterised by thin-skinned tectonics with a near absence of metamorphism and penetrative structures (Julivert 1971; Pérez Estaún et al. 1988). Knowledge of thermal evolution of the rocks during Variscan deformation in this zone is fundamental for discussing factors involved in thermal development, such as burial of the rocks, tectonic superposition due to thrusting, thermal events associated with intrusions and exhumation of the nappes.

Illite crystallinity (IC; Kübler 1967a, b) and the conodont colour alteration index (CAI; Epstein et al. 1977; Rejebian et al. 1987) are two thermal indicators widely applied to the study of diagenetic to low-grade metamorphic conditions of rocks in many regions of the world. However, whereas use of both parameters independently is common, their simultaneous use is not frequent despite their complementary character.

Previous papers dealing with IC in the Cantabrian Zone have been published by Pérez-Estaún (1978), Brime and Pérez-Estaún (1980), Brime (1981, 1985), Aller et al. (1987), Alonso and Brime (1990), Keller and Krumm (1992, 1993), Gutiérrez-Alonso and Nieto (1996) and with CAI by Raven and van der Pluijm (1986). Both IC and CAI have been simultaneously applied in a cross section (Cape Peñ as-Cape Torres) in the northwest of the Cantabrian Zone (García-López et al. 1997).

The study area in the western part of the Cantabrian Zone (Somiedo, La Sobia and Aramo units; Fig. 1) has a nearly complete succession from Cambrian to Carboniferous (Fig. 2) in which, as in the whole Cantabrian Zone, two tectonostratigraphic units are distin- 


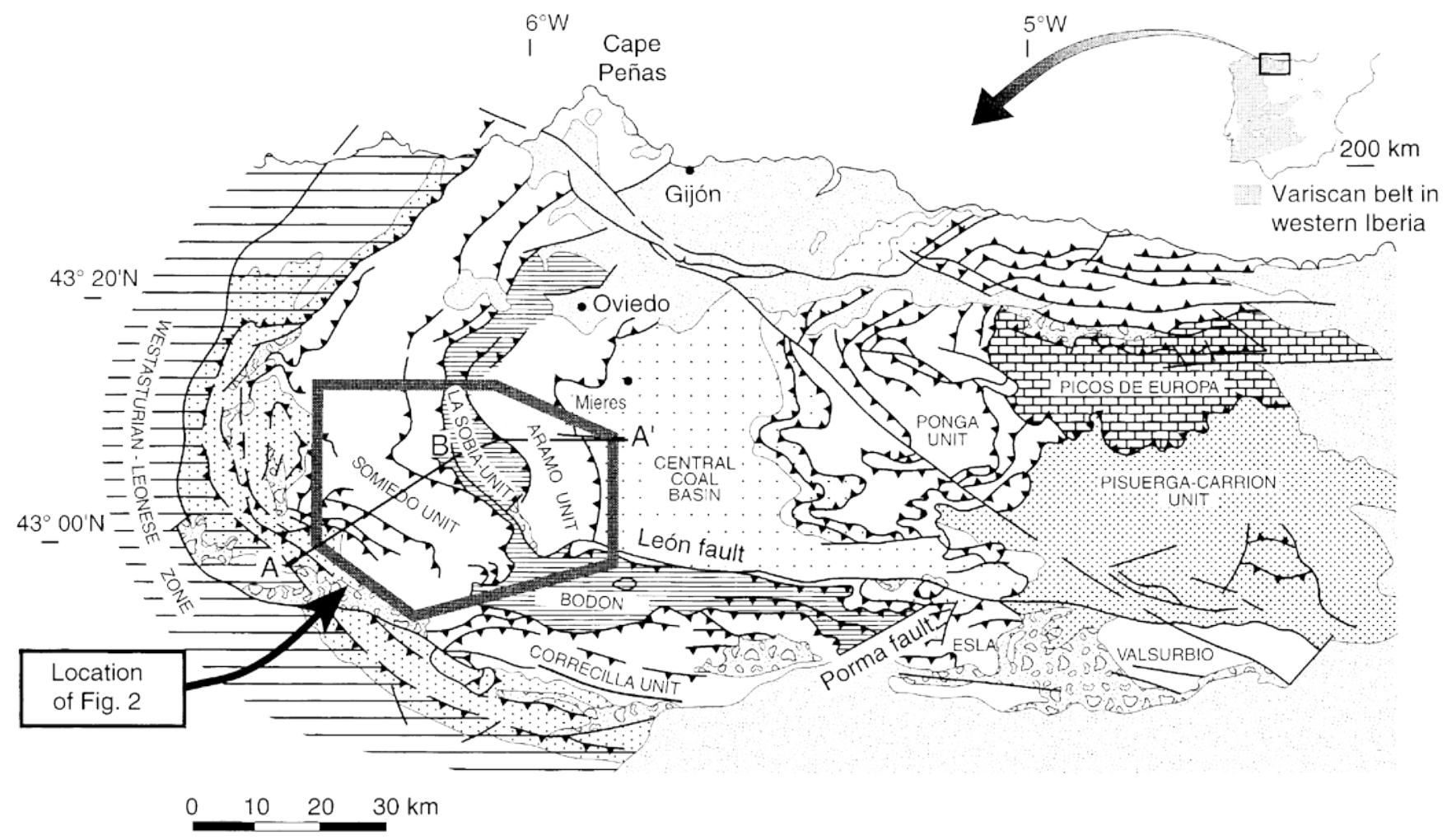

Mesozoic-Tertiary

Cover

Unconformable

Stephanian Rocks

Precambrian

Rocks (Narcea

Antiform)

Paleozoic rocks in the major thrust units of the Cantabrian Zone

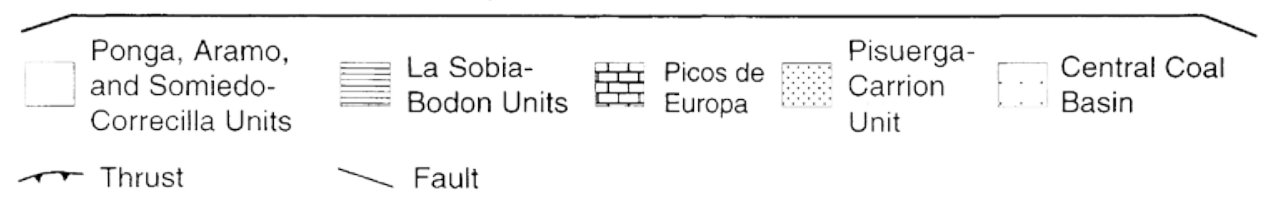

Fig. 1 Generalised map of the Cantabrian Zone with the location of the study zone (after Julivert 1971). A- $A^{\prime}$ and B- $A^{\prime}$ represent traces of the cross sections of Figs. 3 and 7, respectively

guished, one preorogenic and one synorogenic (Julivert 1978; Marcos and Pulgar 1982). The boundary between these units is approximately at the Devonian-Carboniferous boundary. The preorogenic unit consists predominantly of Lower Paleozoic siliciclastics with some carbonate beds (Láncara Formation, LowerMiddle Cambrian), and a Devonian succession with alternation of siliciclastic and carbonate formations. The synorogenic unit has been interpreted as a foreland basin (Julivert 1978; Marcos and Pulgar 1982) which has a coal bearing Carboniferous succession the siliciclastic content of which increases and limestone decreases upward. Stephanian conglomerates with some coal beds exist in some areas and are unconformable over older deposits and commonly have a faulted margin (Fig. 2).

The structure consists of three nappes (Fig. 1). The Somiedo and La Sobia basal thrusts (Figs 2, 3) show a geometry of flats, ramps and associated folds (Julivert et al. 1968; Marcos 1968; Bastida et al. 1984). Their basal part in the map area is generally formed by Cambrian rocks (Láncara limestone), which were usually thrusted over Carboniferous rocks. This structural situation involves the existence of a large frontal footwall ramp in both units (Fig. 3). Longitudinal faultbend folds are associated with frontal structures of the thrusts. The Aramo Unit is formed mainly by Carboniferous rocks thrust over younger Carboniferous rocks of the Central Coal Basin (Aller 1986). Cleavage is sparse in all these units, and diagenetic conditions are thought to be dominant.

The western boundary of the western nappes of the Cantabrian Zone is formed by the Narcea antiform (Fig. 1), marking the beginning of the WestasturianLeonese Zone, where regional metamorphism and cleavage are widely developed. The anchizone-epizone transition occurs in the Narcea antiform. It has been discriminated by illite crystallinity analysis (Pérez Estaún 1978; Aller et al. 1987; Gutiérrez-Alonso and Nieto 1996).

The aim of this paper is the establishment of a model of the thermal evolution in a region affected by thin-skinned tectonics. This model is based on comparison of the distribution and evolution of temperature in the different nappes, relating the thermal conditions 


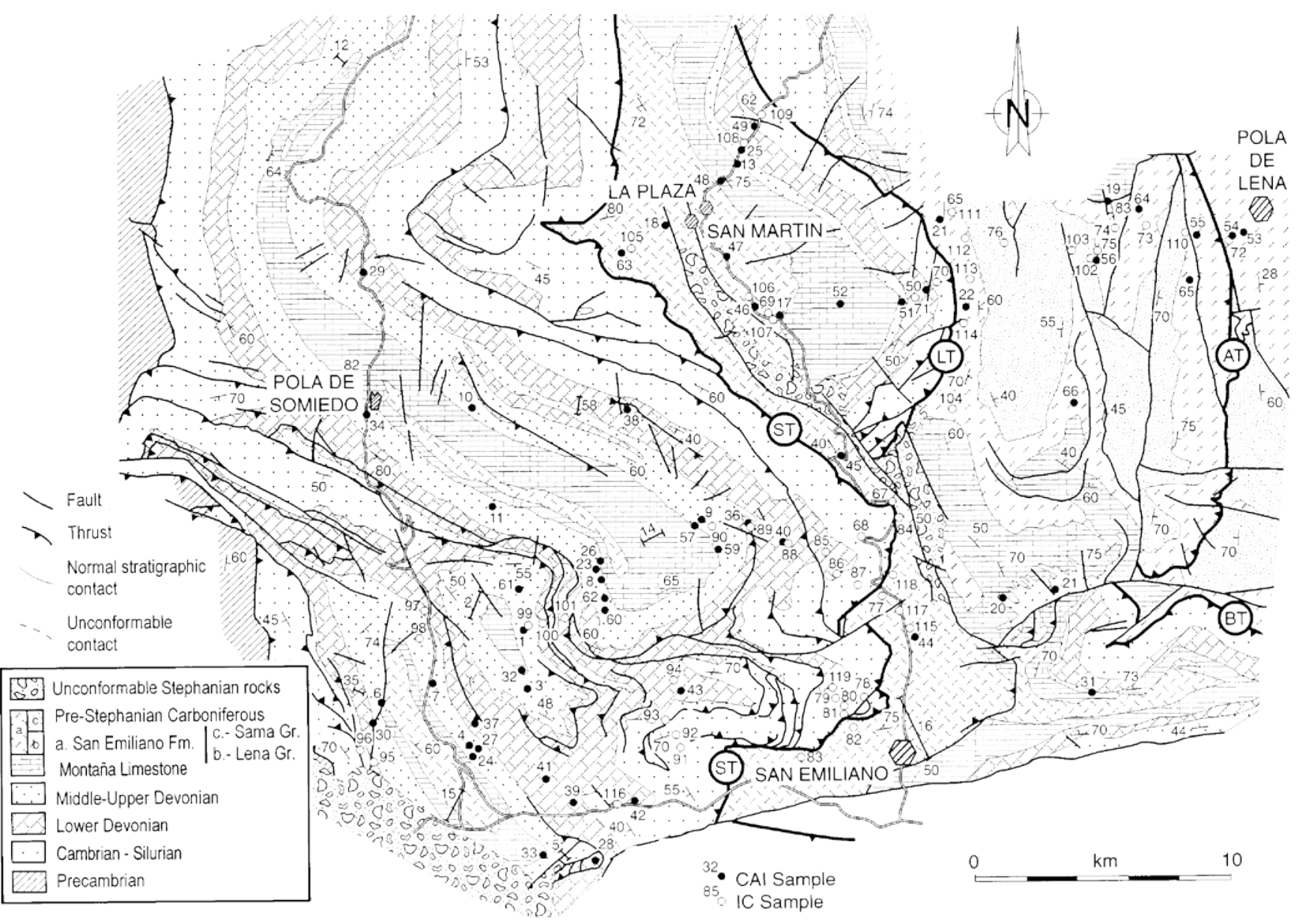

Fig. 2 Map of the western nappes of the Cantabrian Zone (Somiedo, La Sobia and Aramo units) with sampled localities (geology from Julivert et al. 1968, Bastida et al. 1984, and Aller 1986). Basal thrusts of the main units are drawn with thicker lines. ST Somiedo basal thrust; LT La Sobia basal thrust; BT Bodón basal thrust; AT Aramo basal thrust

with emplacement of the major thrusts sheets and evolution of deformation.

\section{Methods}

Conodont colour alteration index

Samples were collected through the southern part of the Somiedo, La Sobia, and Aramo Units. Sampling was complemented with specimens from collections housed at the University of Oviedo (Spain) and those of the National Museum of Natural History at Leiden (The Netherlands). The database used contains up to 507 samples from 63 localities. Unfortunately, recovery of conodonts from Upper Cambrian, Ordovician and Silurian rocks was hindered by their siliciclastic character. Many of the samples from the Aramo Unit were barren. The CAI values are based on specimens from limestone that were treated, usually $5 \mathrm{~kg}$ per sample, and leached with $6 \%$ acetic acid solution.

The CAI values were determined separately by two of the authors (S.G.L. and G.N.S.) in order to reduce bias. Determinations were based on observation of the margin or lighter parts of conodont elements. Colour comparisons were made with a CAI standard set obtained under the direction of A. G. Harris at the USGS, Reston, Virginia. Small variations in CAI values were observed in each sample and appear to be related, in part, to size and shape of the conodonts. This influence of size is more noticeable in samples with CAI values $\sim 3$. In those samples, CAI was determined using only medium-sized specimens. Conodonts were also observed under the SEM to check the relation of surface texture to inferred thermal changes. Terminology employed for the textural description of conodonts in the present paper is based on that used by Königshof (1992) and García-López et al. (1997). Many specimens per sample were used to determine each CAI value. Several CAI values were obtained from most samples. Mean and standard deviation of CAI values were determined for each sample (Table 1) in order to tentatively contour CAI values (Fig. 4).

Temperature ranges of the CAI values were obtained from the Arrhenius plot presented by Epstein et al. (1977) and Rejebian et al. (1987; Table 1). The 


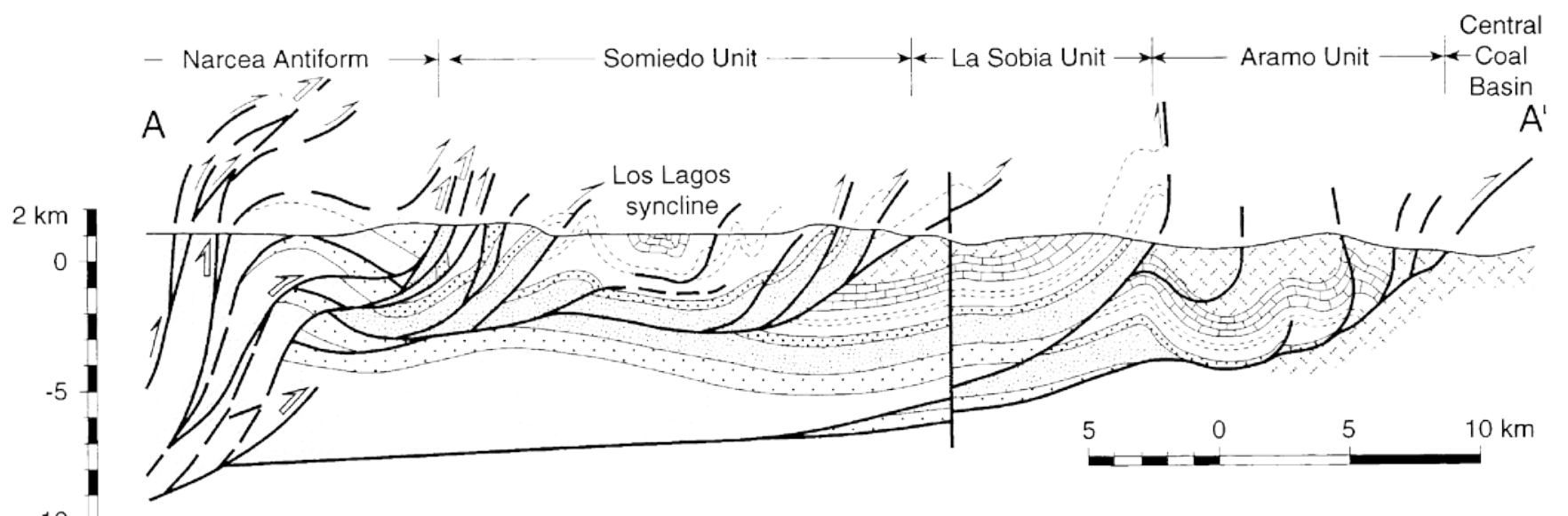

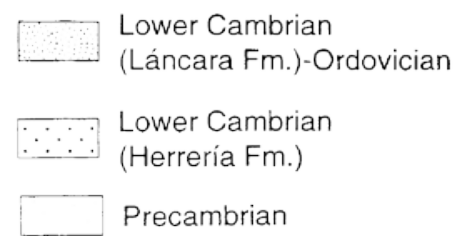

Lower Cambrian

Fig. 3 Geological cross section through the western nappes of the Cantabrian Zone (Somiedo, La Sobia and Aramo units; modified from Pérez Estaún et al. 1988, taking into account seismic data from Pérez Estaún et al. 1994). Location of the cross section in Fig. 1

minimum time of heating of the rocks was $1 \mathrm{Ma}$ following Epstein et al. (1977), whereas the maximum time of heating is the difference between the rock age for each locality and the beginning of the Stephanian (300 Ma), when most of the unloading by erosion in the Cantabrian Zone had just taken place.

Layer silicate mineralogy and illite crystallinity

Pelitic samples were studied by X-ray diffraction (XRD) in order to determine their layer silicate mineralogy and IC index. In preparation for XRD analysis each sample was dispersed in deionised water and disaggregated before separation of the $\sim 2 \mathrm{~mm}$ fraction by settling in a water column. That fraction was sedimented onto glass slides for XRD determinations carried out on a Philips automated PW1730/10 X-ray diffractometer (Philips, Best, The Netherlands), using $\mathrm{CuKa}$ radiation, and graphite monochromator. Mineralogical composition of the major mineral phases was determined after examination of each oriented mount in the air-dried state, after glycol treatment and after heating at $5507 \mathrm{C}$.

The crystallinity of illite, i.e. the width of the firstorder illite basal reflection (10- $\AA$ peak) at half height above background (Kübler 1964), was measured using a laboratory procedure consistent with that outlined by the IGCP 294 work group (Kisch 1991). The numerical value decreases with improving crystallinity and is given in $D 72 u$.
Illites of the diagenetic and the low-grade anchimetamorphic zones commonly show marked asymmetry of the $10 \AA$ diffraction peak, with a low-angle (highspacing) tail, indicating the presence of expandable layers affecting crystallinity (Kübler 1968, 1984). Narrowing of these peaks upon EG solvation appears to be almost ubiquitous. For these reasons IC values were determined in both air-dried and glycolated patterns, so that interference of swelling phases is reduced when considering the values obtained for the glycolated mounts.

The transient zone ("anchizone" of Kübler 1967b) between diagenesis (sensu lato) and the greenschist facies ("epizone" of Kübler 1967b) is defined by $D 72 u$ indices between 0.427 and 0.257 , respectively (Kisch 1991). The values obtained in our laboratory were correlated with Kübler Neûchatel scale using a calibration curve based on data we obtained from samples measured in both Oviedo and Neûchatel laboratories. All IC values quoted in the following text and figures of this study have been converted to Kübler scale by using the following calibration equation:

$$
\mathrm{IC}_{\text {Küblerp }} \mathrm{p} \text { 806!IC } \text { Oviedo } \mathrm{C0.042}\left(\mathrm{R}^{2} \mathrm{p} 0.969\right)
$$

The IC is plotted in Fig. 5 and contoured for equal IC values.

\section{Results}

The CAI values change from 1 to 4.5 through the study area, suggesting a temperature range from 40 to $2807 \mathrm{C}$ (Fig. 4; Table 1). In general, the CAI increases from $\sim 2$ in the core of the synclines to 3-4 in the core of the anticlines, and in the basal part of the nappes, where values higher than 3 are found. This structural control 
Table 1 Colour alteration index (CAI) and temperatures inferred from the Arrhenius plot (Epstein et al. 1977; Rejebian et al. 1987) according to the heating interval of rocks

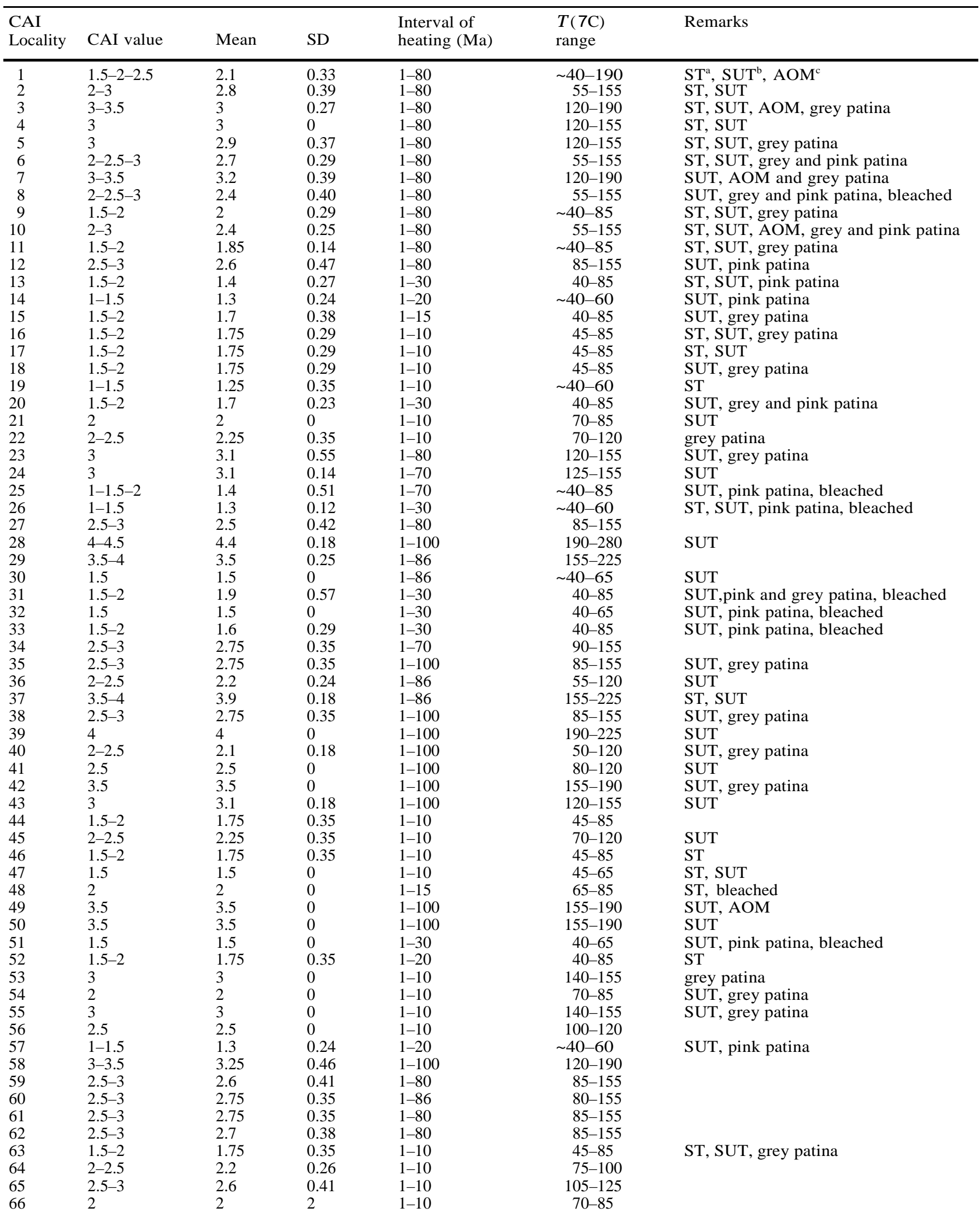




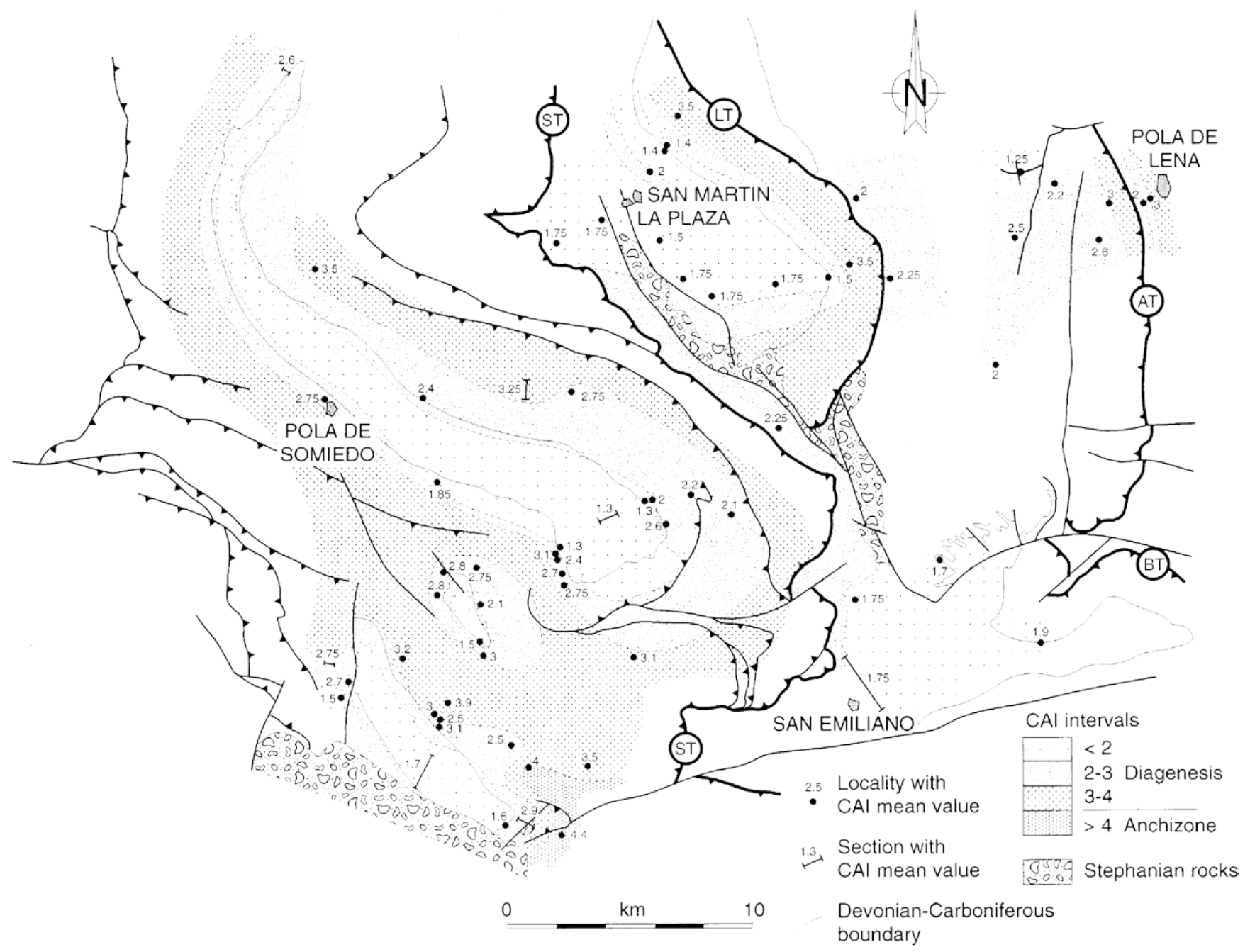

Fig. 4 Map with location of colour alteration index (CAI) values and delimitation of equal CAI contours. Basal thrusts of the main units are drawn with thicker lines. ST Somiedo basal thrust; LT La Sobia basal trhust; BT Bodón basal thrust; AT Aramo basal thrust

coincides with stratigraphic control. The CAI is lower in younger rocks. The basal thrust of the main units disrupts the CAI trend (increasing downwards in each of them), so that the boundary of the units is also a boundary for the CAI trend. The CAI mean values obtained in several localities are relatively low considering the stratigraphic level of the samples. This occurs mainly in bleached conodonts, appearing regularly in the Lower Carboniferous. It suggests a high fluid pressure in the rocks of some areas. According to Epstein et al. (1977) and Rejebian et al. (1987), this would retard the colour alteration of conodonts. As a result, for a given time of heating, the CAI could be lower than in dry conditions.

Most of the conodonts display sugary texture, although smooth surfaces are also frequent. Grey and pink patinas are common. Standard deviation of the
CAI ranges from 0 to 0.57 (Table 1 ). These values correspond to maximum variations of 1 unit in the most common CAI values.

Applying the correlation made in the NW Cantabrian Zone between CAI and IC values for the boundaries of the anchizone (García-López et al. 1997), most of the present study area is within the diagenetic zone. The anchizone (CAI 14) has been recognised in a sample in the southern part of the Somiedo Unit (Fig.4).

The XRD analysis of samples shows that the $\sim 2 \mathrm{~mm}$ phyllosilicate assemblage is dominated throughout by a $10 \AA$ illitic phase accompanied by an ordered mixedlayer illite/smectite (I/S), along with kaolinite and chlorite. Chlorite and kaolinite are present in the $\sim 2 \mathrm{~mm}$ fraction of samples with IC^0.65 $D 72 u$. The presence of significant amounts of I/S has an effect on the IC values determined, and the IC value is overestimated in untreated samples (Fig. 6). Swelling of the I/S component leaves the $10 \AA$ peak free of interference, and thus IC values of glycolated mounts are better reflections of the real IC of the samples. Thus, for subsequent discussions we only use the IC values obtained from glycolated mounts. 


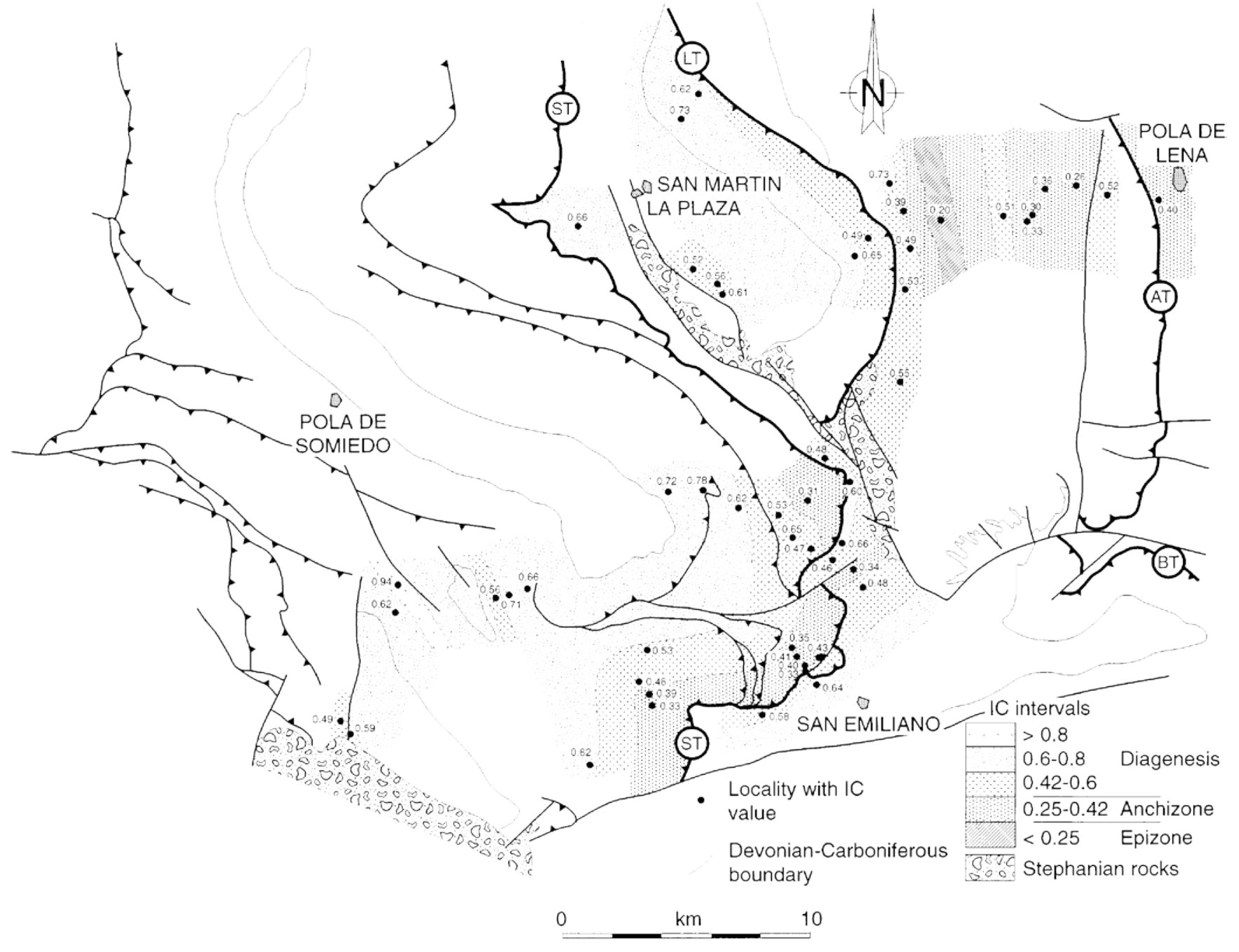

Fig. 5 Map with location of illite crystallinity (IC) values and delimitation of equal IC contours. Basal thrusts of the main units are drawn with thicker lines. ST Somiedo basal thrust; LT La Sobia basal thrust; BT Bodón basal thrust; AT Aramo basal thrust

Analysis of the $\sim 2 \mathrm{~mm}$ fraction of the samples reveals that IC values range between 0.20 and 0.94 $D 72 u$. In the Somiedo Unit, decrease of the IC values occurs towards base of the nappe, where the anchizone is generally reached (Fig. 5). This trend in IC values is less apparent in the La Sobia Unit, where the entire unit remained at diagenetic conditions. In the Aramo Unit the distribution of IC values is not dependent on the stratigraphic location of the sample. Anchizonal IC values appear to be dominant in the Aramo Unit, though epizonal and diagenetic IC values are also present. These IC values contrast with CAI values obtained from the few samples producing conodonts in the Aramo Unit. They always indicate diagenetic conditions (Fig. 4). The Somiedo basal thrust interrupts the trend of a decrease in IC values, but such is not observed for the La Sobia and Aramo basal thrusts.
Spaced cleavage is occasionally observed in the rocks of the lower part in the Somiedo Unit; it is scarce in the lower part of the La Sobia Unit. It occurs mainly in the Lower-Middle Cambrian (Láncara limestone) up to the Lower Devonian (Rañ eces-La Vid Group) in areas with CAI 13 and IC 0.6.

The presence in many localities of a variable thickness (5-10 m, rarely more) of crush breccias and cataclasites associated with the Somiedo basal thrust (Bastida et al. 1984) and the poor development of cleavage suggest dominant brittle conditions during the emplacement of the Somiedo Unit.

\section{Interpretation}

Structural and stratigraphic control on the distribution of CAI and IC values is observed in the study area (Figs. 4, 5). Both distributions show that anchizonal conditions are common in the lower part of the Somiedo Unit. The anchizonal area detected from CAI represents an extension of the anchizonal area detected from IC. Cleavage distribution coincides with the 


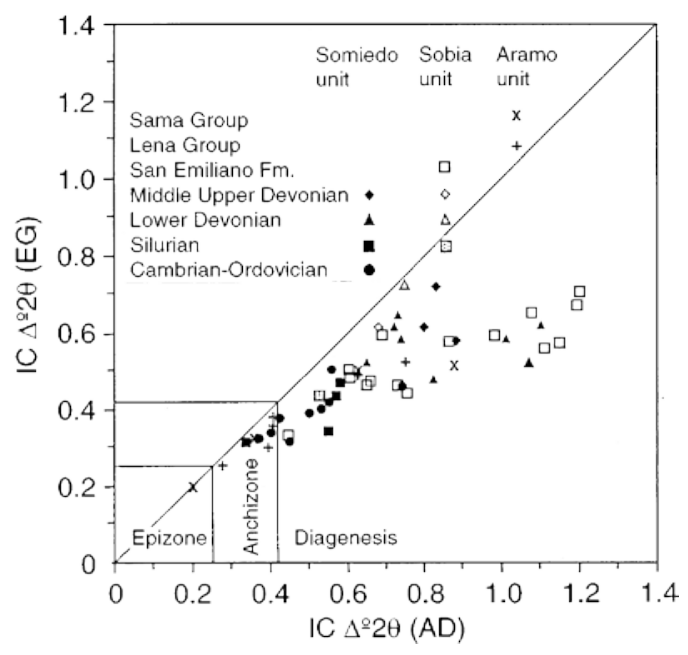

Fig. 6 The upper left part of the figure with the symbols has been changed and now is misleading. The symbols have been moved down and to the right so that they are too close to the sample points. Please change it so that they remain as in the submitted figure

anchizonal and deep diagenesis areas located in this unit. The presence of the anchizone in the lower part of the Somiedo Unit agrees with the results of Brime (1981) and Aller et al. (1987) in the southeastern extension of this unit, where the anchizone was also described in its lower part.

The disruption of the thermal trend by basal thrusts (discontinuous inverted metamorphism of Frey 1988), evidenced by CAI and IC values (Figs. 4, 5), indicates that the thermal peak occurred prior to cessation of emplacement of the nappes. The presence of a thermal discontinuity at the thrusts, with higher grade in the hanging-wall, was pointed out by Brime (1981) and Aller et al. (1987) for the southeastern extension of the Somiedo Unit, and by Raven and van der Pluijm (1986) for the Esla nappe (southern part of the Cantabrian Zone; Fig. 1).

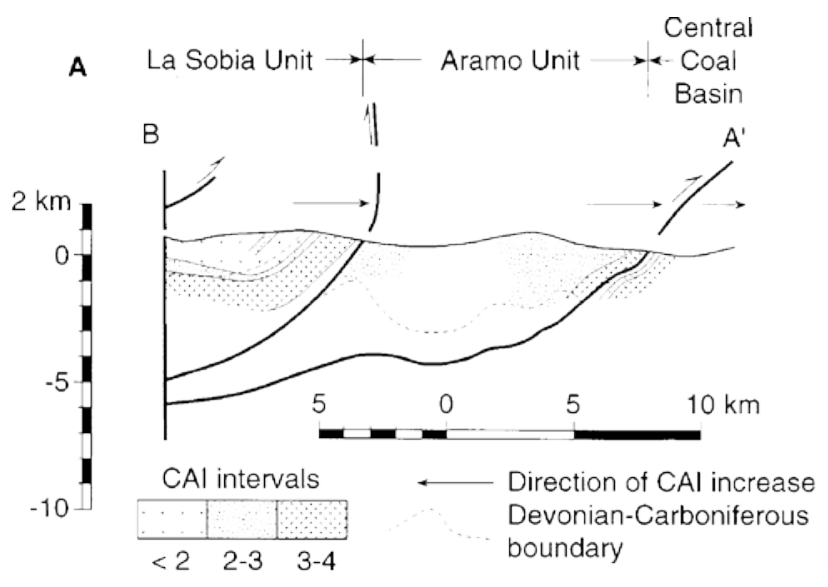

The CAI 2 values in the core of the synclines in the Somiedo Unit indicate mean temperatures of approximately 50-60 7C. Although some authors have doubted whether CAI 1.5 in fact represents such a low temperature (Robinson et al. 1987), this temperature range suggests an overburden for the core rocks of approximately $1 \mathrm{~km}$. Consequently, tectonic superposition by thrusting over the Somiedo Unit was either limited or compensated by erosion in a way similar to that described by Burbank and Beck (1991) in a thrust sheet of the Cenozoic foreland basin of northern Pakistan in which the mean uplift rate was nearly balanced by the rate of denudation.

Both CAI and IC values indicate diagenetic conditions in the La Sobia Unit, but there is disagreement in results for CAI and IC in the Pre-Stephanian Carboniferous rocks in the Aramo Unit (Figs. 4, 5, 7). In this unit, CAI values of 2-3 indicate clearly diagenetic conditions, whereas the IC values indicate mainly anchizonal conditions. Coal rank data from Colmenero and Prado (1993; Fig. 4), in the Aramo Unit, show a volatile content of $18-30 \%$ daf (mainly medium volatile bituminous coal), and using the correlation of major organic maturation indices of Bustin et al. (1990; Fig. 1), equates with a CAI interval of $2-3$, in agreement with the CAI values of the Aramo Unit.

The anomalous IC values for the Upper Carboniferous mudrocks might be the result of the presence of clay minerals inherited from an anchizonal or even epizonal source area. Incorporation of detrital phyllosilicates to the $\sim 2 \mathrm{~mm}$ fraction is a well-known feature (Kübler et al 1991; Warr et al. 1996; Nieto et al. 1996; Lanson et al. 1998; Gharrabi et al. 1998); therefore, when IC results contradict those obtained by other methods, they should be considered with caution. In

Fig. 7 Cross sections showing distribution of metamorphic grade according to A CAI and B IC values. Location of the cross sections in Fig. 1

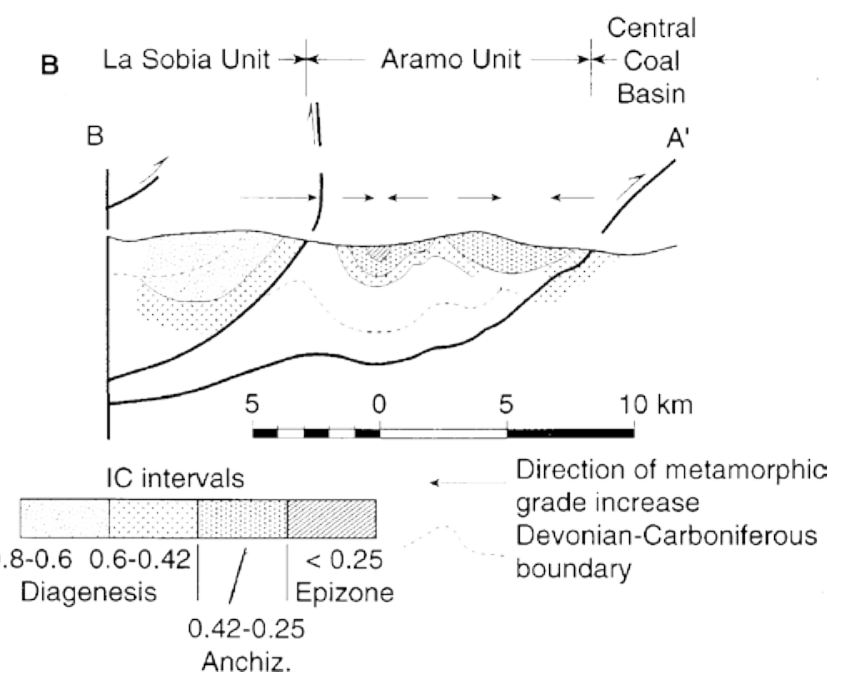


order to confirm the detrital character of illite in the $\sim 2 \mathrm{~mm}$ fraction, two smaller fractions were separated ( $\sim 1$ and $\sim 0.5 \mathrm{~mm}$ ). Diffractograms showed no chlorite and yielded IC values clearly diagenetic, thus confirming the detrital character of the illites of the $\sim 2 \mathrm{~mm}$ fraction and a diagenetic grade for the Aramo unit; hence, the apparent metamorphic conditions of the mudrocks in the Aramo Unit, as indicated by the IC of the $\sim 2 \mathrm{~mm}$ fraction, would in fact reflect the conditions of the rocks of the source area of the sediments. This agrees with the presumed provenance of the siliciclastic sediments of the Lena and Sama groups that were deposited in a foreland basin and derived from erosion of deformed and metamorphosed rocks to the west (Julivert 1978). In fact, in the Narcea Antiform (Fig. 1), west of the study area, the Paleozoic pre- and synorogenic succession was entirely eroded before deposition of the uncorformably overlying Stephanian sequence. A remarkable feature is the presence of an apparent metamorphic inversion indicated by the IC in the Aramo Unit (Figs. 2, 5 and 7B), where, in the core of a syncline, the younger rocks, belonging to the Sama Group, gave a higher grade. This inversion cannot be explained by tectonic superposition; it accords with an apparent metamorphic grade inherited from the source area, since the younger sediments would tend to have arisen from erosion of deeper levels. This interpretation implies erosion of fresh metapelites and rapid transport and deposition to prevent significant transformations of the clay minerals.

The Carboniferous rocks of the San Emiliano Formation in the La Sobia Unit (Fig. 2) are comparable in lithology and age to the rocks of the Lena and Sama groups in the Aramo Unit (Fernández 1993). Nevertheless, diagenetic conditions are indicated by CAI and IC values in the former unit. This suggests a difference in the metamorphic grade of the material being derived from erosion in the source areas of the La Sobia-Bodón and the Aramo Upper Carboniferous clastics wedges, and/or different erosion conditions for both units.

Stratigraphic control on the CAI and IC values is consistent with the presence of anchizonal conditions in the lower part of the Somiedo Unit being a burial effect. In fact, the main effect of the basal thrust could have been emplacement of the anchizone over the Carboniferous rocks. From the thermal point of view, it is possible to discriminate two stages: (a) development of anchimetamorphism and sporadic pressure solution cleavage in the lower part of the hanging-wall (Cambrian to Lower Devonian rocks) during initiation of the nappe motion, when it detached over a flat, and perhaps previously to this initiation; (b) rise of the hanging-wall rocks affected by cleavage and anchimetamorphism on a ramp, and gradual cooling, since tectonic superposition was compensated by erosion; development of fault rocks was enhanced as a result of brittle deformation in the basal part of the nappe.

There is one problem: whether the bottom of the nappes were or were not cooled when they cut the
Upper Carboniferous siliciclastic rocks of their respective footwalls. Evidence of heating of the top of the footwall of the thrusts by the basal part of the nappes has not been clearly discriminated. Only in the southeastern part (San Emiliano area) of the Somiedo Unit (Figs. 4, 5) could this effect be suggested. Such heating was described by Brime (1981) and Aller et al. (1987) in the Correcilla Unit (Fig. 1). The results of these authors suggest that the thrusting units were not completely cooled when they cut the pre-Stephanian Upper Carboniferous rocks, although their effect on the footwall rocks was probably not significant in many cases within the area studied there.

The Somiedo Unit is the westernmost nappe of the Cantabrian Zone; its root is located in the Precambrian rocks of the Narcea Antiform, west of the study area (Fig. 3), where the general front of Variscan orogenic metamorphism is located (Capdevila 1969; PérezEstaún 1978; Brime 1985). Very low-grade metamorphism of the lower part of the Somiedo Unit could represent an extension of this metamorphism, displaced eastwards by the Somiedo basal thrust.

The age of the metamorphism has been generally accepted as Variscan in the internal zone of the Iberian Massif in NW Spain (Capdevila 1969), and as Variscan or even post-Variscan for localised metamorphism of the external zone (Cantabrian Zone; Aller and Brime 1985; Raven and van der Pluijm 1986). Nevertheless, from IC data in several areas of the Cantabrian Zone, including the Somiedo Unit, and based on a supposed discontinuity across the Ordovician-Silurian boundary, the trend of IC values along the Paleozoic succession, according to Keller and Krumm (1992, 1993), supports discrimination of an Upper Ordovician metamorphic event coinciding with that hiatus. Nevertheless, variations in IC values shown by these authors can be interpreted also by decrease in IC with depth (Figs. 3, 4; Keller and Krumm 1993). In fact, in keeping with IC values of the present study, there are some Silurian anchizonal samples and, exceptionally, some Cambrian-Ordovician diagenetic samples. A lack of deformation and overburden for the Cambrian-Ordovician rocks in the Cantabrian Zone, prior to the Upper Ordovician, is hardly compatible with Upper Ordovician regional metamorphism. The rare manifestations of magmatic activity in the western nappes of the Cantabrian Zone could imply development of a local but not regional metamorphism.

The anchizone of the lower part of the Somiedo Unit is here interpreted as Variscan. Nevertheless, another low-grade metamorphic event has been described by several authors in other areas of the Cantabrian Zone (Koopmans 1962; Lobato 1977; Aller and Brime 1985; Raven and van der Pluijm 1986; Aller et al. 1987; Alonso and Brime 1990). This metamorphism, which probably affects also Stephanian rocks as suggested by coal rank data (Colmenero and Prado 1993), has associated cleavage and is independent of the one described in the present paper. It has been 
interpreted as a late- or post-Variscan thermal event. In the study area, the only effect of this late metamorphism appears possibly in the unconformably overlying Stephanian rocks adjacent to the termination of the Leon fault (Fig. 1), where coal rank (low volatile bituminous coal) is greater than that of the pre-Stephanian Carboniferous rocks (Fig. 4; Colmenero and Prado 1993).

\section{Conclusion}

The combined use of CAI and IC to assess the distribution of the thermal conditions in the western nappes of the Cantabrian Zone provides evidence of anchizonal conditions in the lower part of the Somiedo Unit. This anchizone represents a last vestige of the Variscan orogenic metamorphism the general front of which was located in the Precambrian rocks of the Narcea Antiform, where the root of the Somiedo Unit is located. Cleavage appears in some areas with CAI 13 and IC 0.6.

Diagenetic conditions were dominant in the $\mathrm{La}$ Sobia Unit and probably in the Aramo Unit; in the latter, CAI data indicate diagenetic conditions, whereas IC data of the $\sim 2 \mathrm{~mm}$ fraction indicate mainly anchizonal conditions. According to the IC results obtained from the smaller fractions, this apparent contradiction has been interpreted as a feature inherited from the source area implying erosion of fresh metapelites and rapid transport and deposition. The Carboniferous mudrocks of the La Sobia Unit have diagenetic IC and CAI values suggesting different thermal conditions for the rocks of the source area from those of the equivalent rocks of the Aramo Unit, or different erosion conditions. Thus, the combined use of several thermal indicators has proven to be a powerful tool for unravelling the geological history of a problematic area.

Temperatures suggested by CAI data for the preStephanian Carboniferous rocks of the Somiedo Unit are approximately 50-60 7C and are in agreement with an overburden of approximately $1 \mathrm{~km}$. Slightly higher temperatures and overburden are inferred for Carboniferous synorogenic siliciclastic rocks in the La Sobia Unit. This overburden indicates that the tectonic superposition by thrusting over this unit was either limited or compensated by erosion.

The presence of abnormally low CAI values in several localities and the abundance of patinas on the conodonts suggest a high fluid pressure within the rocks in some areas.

Breaks in thermal trend for the basal thrusts (Figs. 4, 5) indicate an age for the thermal peak prior to termination of nappe emplacement. Tectono-thermal evolution in two stages is proposed for the Somiedo Unit: (a) development of anchimetamorphism in the lower part of the hanging-wall before and/or during its translation over a flat; and (b) rise of the cleaved and metamorphosed lower part of the nappe over a long ramp, erosion and cooling of the sheet and enhancement of the formation of fault rocks due to brittle deformation in the basal part of the unit.

Stratigraphic position had a notable control on the metamorphic grade in the western Cantabrian nappes. Tectonic stress gave rise to sporadic pressure solution cleavage involving some textural changes and locally enhancing the effect of the stratigraphic burial. Overburden due to thrusting was limited and had little influence in the development of metamorphism.

In the context of the Iberian Variscan belt in northwest Spain, the effect of the tectonic overburden on the regional metamorphism probably decreased from internal to external parts of the orogen parallel to a relative increasing role of the stratigraphic burial and a general decrease of metamorphic grade until diagenetic conditions were dominant in the Cantabrian Zone. Influence of tectonic factors on the metamorphism is greater in the internal parts, where the strain and cleavage are always present, than in the external parts, where brittle deformation and rock translation are dominant.

Acknowledgements The present work was supported by Spanish DGE 95-PB1047 project. We thank J. Aller, D. Robinson and J.A. Talent for the constructive review of a previous version of the paper. Thanks to the referees S. Krumm and F. Nieto for their critical and helpful comments.

\section{References}

Aller J (1986) La estructura del sector meridional del las unidades del Aramo y de la Cuenca Carbonífera Central. Principado de Asturias, pp 1-180

Aller J, Brime C (1985) Deformación y metamorfismo en la parte Sur de la Cuenca Carbonífera Central (NO de España). C R X Congrès Int Strat Géol Carbonifère 3:541-548

Aller J, Bastida F, Brime C, Pérez-Estaún A (1987) Cleavage and its relation with metamorphic grade in the Cantabrian Zone (Hercynian of North-West Spain). Sci Géol Bull 40:255-272

Alonso OE, Brime C (1990) Mineralogy, geochemistry, and origin of the underclays of the Central Coal Basin, Asturias, Spain. Clays and Clay Mineral 38:265-276

Bastida F, Marcos A, Pérez-Estaún A, Pulgar JA (1984) Geometría y evolución estructural del Manto de Somiedo (Zona Cantábrica, NO España). Bol Geol Min 95:517-539

Brime C (1981) Postdepositional transformation of clays in Palaeozoic rocks of northwest Spain. Clay Minerals $16: 421-424$

Brime C (1985) A diagenesis to metamorphism transition in the Hercynian of NW Spain. Mineral Mag 49:481-484

Brime C, Pérez-Estaún A (1980) La transición diagénesis-metamorfismo en la región de Cabo Peñ as. Cuadernos Lab Geol Laxe 1:85-97

Burbank DW, Beck RA (1991) Rapid, long-term rates of denudation. Geology 19:1169-1172

Bustin RM, Barnes MA, Barnes WC (1990) Determining levels of organic diagenesis in sediments and fossil fuels. Geosci Canada 4:205-226

Capdevila R (1969) Le métamorphisme régional progressif et les granites dans le segment hercynien de Galice nord-orientales (NW de l'Espagne). Thesis, Université de Montpellier, pp 1-430

Colmenero JR, Prado JG (1993) Coal basins in the Cantabrian Mountain, northwestern Spain. Int J Coal Geol 23:215-229 
Epstein AG, Epstein JB, Harris LD (1977) Conodont Colour Alteration -an Index to Organic metamorphism. U. S. Geol Surv, Prof Paper 995:1-27

Fernández LP (1993) La Formación San Emiliano (Carbonífero de la Zona Cantábrica, NO de Españ a): estratigrafía y extensión lateral. Algunas implicaciones paleogeográficas. Trab Geol Univ Oviedo 19:97-122

Frey M (1988) Discontinuous inverse metamorphic zonation, Glarus Alps, Switzerland: evidence from illite "crystallinity" data. Schweiz Mineral Petrogr Mitt 68:171-183

García-López S, Brime C, Bastida F, Sarmiento GN (1997) Simultaneous use of thermal indicators to analyse the transition from diagenesis to metamorphism: an example from the Variscan Belt of northwest Spain. Geol Mag 134:323-334

Gharrabi M, Velde B, Sagon JP (1998) The transformation of illite to muscovite in pelitic rocks: constraints from X-ray diffraction. Clay Minerals 46:79-88

Gutiérrez-Alonso G, Nieto F (1996) White-mica “crystallinity” finite strain and cleavage development across a large Variscan structure, NW Spain. J Geol Soc Lond 153:287-299

Julivert M (1971) Décollement tectonics in the Hercynian Cordillera of NW Spain. Am J Sci 270:1-29

Julivert M (1978) Hercynian orogeny and Carboniferous paleogeography in northwestern Spain: a model of deformation-sedimentation relationships. Z Dtsch Geol Ges 129:565-592

Julivert M, Pello J, Fernández-García L (1968) La estructura del Manto de Somiedo (Cordillera Cantábrica). Trab Geol Univ Oviedo 2:1-44

Keller M, Krumm S (1992) Evidence of an Upper Ordovician thermo-metamorphic event in the SW-corner of the Cantabrian Mountains (N-Spain). Estudios Geol 48:289-296

Keller M, Krumm S (1993) Variscan versus Caledonian and Precambrian metamorphic events in the Cantabrian Mountains, northern Spain. Z Dtsch Geol Ges 144:88-103

Kisch HJ (1991) Illite crystallinity: recommendations on sample preparation, X-ray diffraction settings and interlaboratory samples. J Metam Geol 9:665-670

Königshof P (1992) Der Farbänderungsindex von Conodonten (CAI) in paläozoischen Gesteinen (Mitteldevon bis Unterkarbon) des Rheinischen Schiefergebirges Eine Ergänzung zur Vitrinitreflexion. Courier Forschungsinstitut Senckenberg $146: 1-118$

Koopmans BN (1962) The sedimentary and structural history of the Valsurvio Dome (Cantabrian Mountains, Spain). Leid Geol Meded 26:131-232

Kübler B (1964) Les argiles, indicateurs de métamorphisme. Rev Inst France Pétrole 19:1093-1112

Kübler B (1967a) La cristallinité de l'illite et les zones tout à fait supérieures du métamorphism. Etages tectoniques, Coll Neuchâtel 105-122

Kübler B (1967b) Anchimétamorphism et schistosité. Bull Centre Rech Pau-SNPA 1:259-278

Kübler B (1968) Evaluation quantitative du métamorphisme par la cristallinité de l'illite. Bull Centre Rech Pau-SNPA 2:385-397
Kübler B (1984) Les indicateurs des transformations physiques et chimiques dans la diagenèse, temperature et calorimetrie. Soc Française Min Crist, Paris, pp 479-596

Kübler B, Faílla A, Ruch P, Jantschik R, Huon S, Adatte Th, Turberg P, Schwalb A (1991) Detrital mineral association and "illite crystallinity" from recent sediments to very low grade metamorphism as a result of the systematic use of deconvolution. Low -temperature metamorphic processes in contrasting geodynamic settings. Auckland Book of Abstracts, p 29

Lanson B, Velde B, Meunier A (1998) Late-stage diagenesis of illtic clay minerals as seen by decomposition of X-ray diffraction patterns: contrasted behaviors of sedimentary basins with different burial histories. Clay Minerals 46:69-78

Lobato L (1977) Geología de los valles altos de los ríos Esla, Yuso, Carrión y Deva (NW León, NW Palencia y SW Santander). Institución Fray Bernardino de Sahagún (CSIC), León, pp 1-133

Marcos A (1968) La tectónica de la Unidad de La Sobia-Bodón. Trab Geol Univ Oviedo 2:59-87

Marcos A, Pulgar JA (1982) An approach to the tectonostratigraphic evolution of the Cantabrian foreland thrust and fold belt, Hercynian Cordillera of NW Spain. N Jahrb Geol Paläontol 163:256-260

Nieto F, Ortega-Huertas M, Peacor DR, Arostegui J (1996) Evolution of illite/smectite from early diagenesis through incipient metamorphism in sediments of the Basque-Cantabrian Basin. Clay Minerals 44:304-323

Pérez-Estaún A (1978) Estratigrafía y estructura de la rama Sur de la Zona Asturoccidental-Leonesa. Mem Inst Geol Min España 92:1-144

Pérez-Estaún A, Bastida F, Alonso JL, Marquínez J, Aller J, Álvarez-Marrón J, Marcos A, Pulgar JA (1988) A thinskinned tectonics model for an arcuate fold and thrust belt: the Cantabrian Zone (Variscan Ibero-Armorican Arc). Tectonics 7:517-537

Pérez-Estaún A, Pulgar JA, Banda E, Álvarez-Marrón J, ESCI-N Research Group (1994) Crustal structure of the external variscides in northwest Spain from deep seismic reflection profiling. Tectonophysics 232:91-118

Raven JGM, van der Pluijm BA (1986) Metamorphic fluids and transtension in the Cantabrian Mountains of northern Spain: an application of the conodont colour alteration index. Geol Mag 123:673-681

Rejebian VA, Harris AG, Huebner JS (1987) Conodont colour and textural alteration: an index to regional metamorphism and hydrothermal alteration. Geol Soc Am Bull 99:471-479

Robinson D, Wade DN, Burnett R (1987) Correlation between organic and inorganic thermal maturation indices in Palaeozoic basins of Britain. In: Brooks J, Glennie K (eds) Petroleum geology of North West Europe. Graham and Trotman, London, pp 235-244

Warr LN, Greiling RO, Zachrisson E (1996) Thrust-related very low grade metamorphism in the marginal part of an orogenic wedge, Scandinavian Caledonides. Tectonics 15:1213-1229 
F. Bastida; C. Brime; S. García-López G.

N. Sarmiento

\section{Tectono-thermal evolution in a region with thin-skinned tectonics: the western nappes in the Cantabrian Zone (Variscan belt of NW Spain)}

Unfortunately, Fig. 6 was not printed correctly in the above article. Please find the corrected version of this figure as follows:

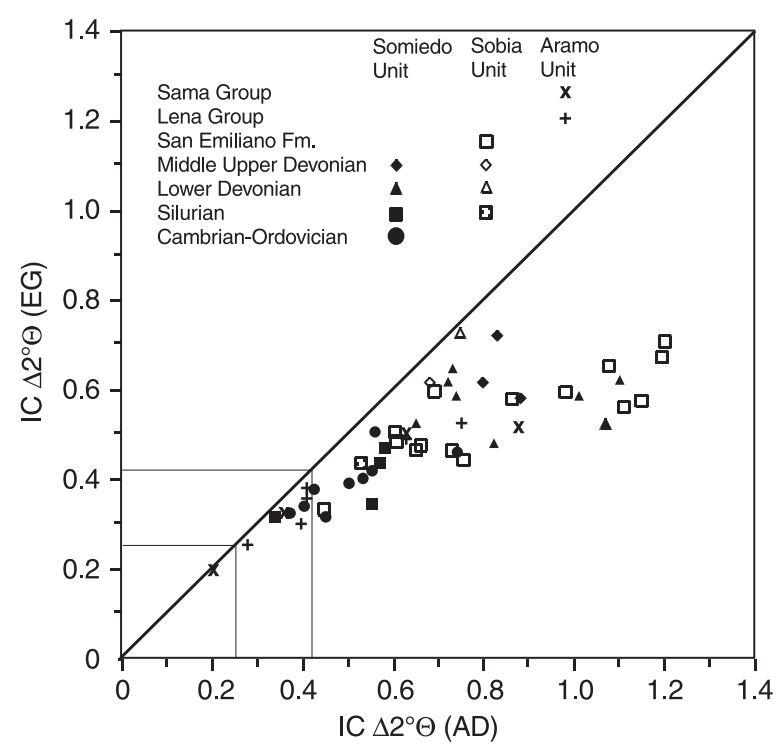

Fig. 6 Illite crystallinity of air-dried samples $(A D)$ vs illite crystallinity of ethylene-glycol solvated samples $(E G)$ 